\title{
Abram the One from Beyond-the-River, and King Chedorlaomer of Elam (Genesis 14): Persia and the Formation of Judaean Ethnic Identity in a Late Patriarchal Narrative
}

\author{
Gard Granerød (D)
}

check for

updates

Citation: Granerød, Gard. 2021. Abram the One from Beyond-the-River and King Chedorlaomer of Elam (Genesis 14): Persia and the Formation of Judaean Ethnic Identity in a Late Patriarchal Narrative. Religions 12: 632. https://doi.org/ $10.3390 /$ rel12080632

Academic Editors:

Kristin Joachimsen, Marianne Hafnor Bøe and Gwynn Kessler

Received: 5 May 2021

Accepted: 14 July 2021

Published: 11 August 202

Publisher's Note: MDPI stays neutra with regard to jurisdictional claims in published maps and institutional affiliations.

Copyright: (C) 2021 by the author Licensee MDPI, Basel, Switzerland. This article is an open access article distributed under the terms and conditions of the Creative Commons Attribution (CC BY) license (https:// creativecommons.org/licenses/by/ $4.0 /$ )
Hebrew Bible/Old Testament Department, MF Norwegian School of Theology, Religion and Society, P.O. Box 5144 Majorstuen, N-0302 Oslo, Norway; gard.granerod@mf.no

\begin{abstract}
The perception of Persia in Judaean/Jewish texts from antiquity contributed to the construction of a Judaean/Jewish identity. Genesis 14 gives an example of this; in it, Abra(ha)m wages war with a coalition headed by King Chedorlaomer of Elam. The article argues that Genesis 14 is one of the latest additions to the patriarchal narratives (Genesis 12-36), composed in the Persian or early Hellenistic period. It was conceived and used as an ethnic identity-forming story. The characters in the narrative represented groups and nations in the neighbourhood of the province of Judah. Abra(ha)m was perceived as the ancestor of the Judaeans and the inhabitants of the province Beyond-the-River. The King of Elam represented the Persian Empire. The article uses redaction criticism to argue that Genesis 14 is among the latest additions to the patriarchal narrative in the late Persian or Hellenistic period. Moreover, it uses a combination of philological and historical methods to argue that the description of Abra(ha)m as hä ibrî (traditionally translated "the Hebrew," Gen 14: 13) characterises him as a person from the region Eber-nāri (Beyond-the-River). The article uses similar methods to argue that the names of people and places in Genesis 14 referred to political entities in and around Judah. Eventually, the article uses Anthony D. Smith's theory of ethnic community and elements from postcolonial theory as "reading lenses" and a framework for analysing Genesis 14. Reading this way underscores that Genesis 14 originated and worked as an ethnic identity-forming story.
\end{abstract}

Keywords: Persian period; Hellenistic period; Elam; the province of Judah; construction of Jewish identity; patriarchal narratives; Hebrew; Genesis 14

\section{Introduction}

The narrative in Genesis 14 chronicles the campaign of King Chedorlaomer of Elam and his coalition and the patriarch Abram's war with the invaders. The events take place in the land that Yahweh had promised to the patriarch. This narrative is probably a source of how Judaeans/Yehudites/Jews ${ }^{1}$ in antiquity perceived themselves in relation to the Persian Empire. The present article is conceived in response to the call for articles to the special issue of Religions with the title "Constructions of Persian and Iranian Identity, Ethnicity, and Religion from Ancient Times to the Present." The article takes the special issue's stress on so-called cultural imagination (defined as "how a group is constructed through narratives, practices, symbols, memory, and [imaginary worlds of] objects, people, or events") as its departure point. Particularly relevant here is the call's emphasis on how one's self and others are construed in terms of ethnic identity markers, as well as how the imperial setting impacts identity constructions. The study asks when and how Genesis 14 was composed, how people in antiquity understood Elam to represent Persia, and what role Abram's war with Elam played in forming a Judaean ethnic identity. The article suggests that the narrative was conceived and worked as an ethnic identity-forming story in the Persian or early Hellenistic period. When the narrative was composed, its characters represented groups and nations in the province of Judah's past and present 
neighbourhood. The Abram ${ }^{2}$ character of the narrative was perceived as the Judaeans' ancestor; the other minor characters (Lot and the five Canaanite kings) were representatives of the neighbouring ethnic groups. King Chedorlaomer of Elam and his coalition represented the Persian Empire.

The first section of this article (Genesis 14 and Its Literary Context), introduces Genesis $14^{* 3}$ and the literary context of its narrative. First, it outlines the compositional history of the so-called patriarchal narratives (Gen 12-36) and Genesis $14^{*}$ in particular. Moreover, it asks what factors triggered the composition of Genesis $14^{*}$. Furthermore, it asks what territorial implications the narrative in Genesis $14^{*}$ had, given that it was composed in the Persian or early Hellenistic period.

The next section (The Reference and Perception of Elam and the Other Friends and Foes of Abram) asks what nations and territories the names of Abram's friends and enemies referred to, provided that Genesis $14^{*}$ was composed in the Persian or early Hellenistic period. It asks if the phrase "Abram $h \bar{a} i b r \hat{\imath}$ " denotes Abram as an individual coming from the region Eber-nāri (Beyond-the-River). Moreover, the section discusses what ethnic entities the Judaeans/Jews in antiquity associated with King Chedorlaomer of Elam, Lot, and the five Canaanite kings.

The last section (Genesis 14*, Anthony D. Smith's Theory of Ethnic Community, and Postcolonial Theory) explores how a reading of Genesis $14^{*}$ through the lens of Anthony D. Smith's theory of ethnic community advances our understanding of how the text in antiquity may have contributed to the construction and maintenance of a Judaean/Jewish ethnic identity. Also, it hints at how elements of postcolonial theory can enrich a historically oriented and sociologically informed reading of Genesis $14^{*}$.

\section{Genesis 14 and Its Literary Context}

Genesis 14 offers a narrative significantly different from the rest of the patriarchal narratives in the Book of Genesis (Gen 12-36). Due to its content and form, it stands out. Nowhere else in the Pentateuch is there talk of a comparable military conflict involving rebelling suzerains and coalitions of international powers quelling revolts. Elsewhere, $\mathrm{Abra}(\mathrm{ha}) \mathrm{m}$, Isaac, and Jacob are patres familias, and the narratives are about family issues. Now, family matters are also present in Genesis 14; Abram rescues his kin Lot. However, outside Genesis 14, the patriarchs do not face allegedly historically identifiable political leaders and nowhere else does a patriarch appear as a player on the international political scene. This way of connecting events in a patriarch's life to the more extensive world history is unique within the patriarchal narratives. Moreover, a stylistic feature that distinguishes Genesis 14 is its abundance of names and detailed itineraries (Granerød 2010, pp. 25-46).

The chapter consists of three parts (Westermann 1985, p. 190; cf. Emerton 1990):

- A campaign account in annalistic style (roughly Gen 14: 1-11)

- A hero narrative about the patriarch (roughly Gen 14: 12-17, 21-24)

- A narrative episode about Abram's meeting with Melchizedek, King of Salem and priest of El Elyon ("God Most High", Gen 14: 18-20)

The campaign account (Gen 14: 1-11) and the hero story (Gen 14: 12-17, 21-24) appear to be integral, whereas the Melchizedek episode seems to be a secondary insertion into the narrative framework, ${ }^{4}$ added at a later point and composed for its present context (Germany 2020, p. 525). Therefore, the present study will refer to the chapter's original core as Genesis $14^{*}$ (that is, chapter 14 without verses 18-20).

The campaign account offers detailed chronological and topographical data. It relates that a coalition of four kings (King Amraphel of Shinar, King Arioch of Ellasar, King Chedorlaomer of Elam, and King Tidal of Goiim, Gen 14: 1,9) waged war against the five Penatapolis kings (King Bera of Sodom, King Birsha of Gomorrah, King Shinab of Admah, and King Shemeber of Zeboiim, Gen 14: 2). It all happened in the region of the Dead Sea (Hebrew: Salt Sea). The report subsumes the four-king coalition under the name Chedorlaomer (Gen 14: 4) and the phrase "Chedorlaomer and the kings who were with him" (Gen 14: 5, 17). Moreover, according to the report, the five Canaanite kings (the 
co-called Pentapolis kings) had been a suzerain under the King of Elam for twelve years. For thirteen years (or, possibly, in the thirteenth year), they revolted, and in the fourteenth year, the King of Elam and his coalition undertook a military campaign that also affected places and peoples other than the Pentapolis kings. The account claims that the Pentapolis kings went into battle with the four-king coalition headed by King Chedorlaomer of Elam but were defeated and forced to flee. Afterward, Chedorlaomer's coalition took booty from the defeated kings. Eventually, the transition between the campaign account and the hero narrative informs readers that Chedorlaomer's coalition took Abram's nephew Lot and his goods (Gen 14: 11-12).

The hero narrative about the patriarch presupposes and continues the campaign account. At the same time, it changes the focus to "Abram the Hebrew" (Gen 14: 13) and his actions. When Abram heard that his nephew Lot had been taken captive, he mobilised an army of 318 men and went in pursuit. Abram went to Dan, where he beat Chedorlaomer's coalition in a nocturnal raid and after that pursued it further to "Hobah, north of Damascus" (Gen 14: 14-15). Then Abram returned all the goods the invaders had seized, his relative Lot "and the women and the people" (Gen 14: 16). After a brief interluding episode (when/where Abram meets Melchizedek, King of Salem and priest of El Elyon, Gen 14: 18-20), the hero story continues, relating that the King of Sodom addresses Abram. The King asks for the release of the people and offers Abram the goods. Abram accepts the goods for his allies and men but refuses to accept anything for himself so that the King cannot say, "I have made Abram rich". (Gen 14: 21-24).

Essential themes in the patriarchal narratives are Yahweh's promise of land and offspring to the patriarchs and their actions that jeopardise these promises. On a literary level in the received, biblical version of the patriarchal narratives, the promises form a "red thread" that unite the narratives about Abr(ah)am, Isaac, and Jacob (Gen 12: 1-3, 7; 13: 14-17; 15; 18: 17-18; 22: 15-18; 26: 3-5; 24; 28: 13-15; 32: 12 [13]; 46: 1-4). Many scholars argue that the promise texts represent an element that was added late in the compositional history of the patriarchal narratives (Rendtorff 1985, pp. 157-63; Köckert 1988, pp. 248-99, 313-23; Köckert 2017, p. 259; Rofé 1999, pp. 98-99; Kratz 2005, pp. 260-74). Thus, the land motif envelopes Genesis 14*. The preceding chapter's narrative depicts a conflict of land between Abram and his relative Lot (Gen 13: 5-9). Abram and Lot settle the conflict through Lot's choosing for himself "all the plain of Jordan" and subsequent journeying eastwards (Gen 13: 11), and Abram's settling in "the land of Canaan" (Gen 13: 12). Genesis 13 concludes with Yahweh appearing to Abram in a theophany (Gen 13: 14-17). In Genesis 13: 14-16, Yahweh calls Abram to view the land he promises to give him and his offspring as an eternal possession. In the following verse (v. 17), Yahweh commands Abram to carry out a concrete action: to walk through the land's length and breadth. Yahweh states that he will give the land to Abram:

The LORD said to Abram, after Lot had separated from him, "Raise your eyes now, and look from the place where you are, northward and southward and eastward and westward; for all the land that you see I will give to you and to your offspring forever. I will make your offspring like the dust of the earth; so that if one can count the dust of the earth, your offspring also can be counted. Rise up, walk through the length and the breadth of the land, for I will give it to you". (Gen 13: 14-17 NRSV ${ }^{5}$ )

Genesis 13: 18 is a brief note, according to which Abram "moved his tent, and came and settled by the oaks of Mamre, which are at Hebron", and where he also built an altar.

Additionally, in Genesis 15, immediately after Genesis $14^{*}$, the promise of land to Abram is important (together with the promise of offspring). In connection with the covenant ceremony presented in Genesis 15, Yahweh presents himself to Abram as the one "who brought you from Ur of the Chaldeans, to give you this land to possess" (Gen 15: 7). Moreover, Yahweh addresses Abram in a dream and confirms that Abram's offspring shall dwell in the land (after having been slaves in a foreign land for three generations; Gen 15: 16). Last but not least, Yahweh makes a covenant with Abram and states: 
[T] your descendants I give this land, from the river of Egypt to the great river, the river Euphrates, the land of the Kenites, the Kenizzites, the Kadmonites, the Hittites, the Perizzites, the Rephaim, the Amorites, the Canaanites, the Girgashites, and the Jebusites. (Gen 15: 18-21 NRSV)

\subsection{Date of Composition of Genesis $14^{*}$}

The questions regarding the date of composition of Genesis $14^{*}$ and what may have triggered its author to compose and insert it into the patriarchal narratives are complicated. The questions are closely connected to the complex compositional history of the patriarchal narratives (Gen 12-36) and the Abraham narratives (Gen 12-25) in particular. However, regarding Genesis $14^{*}$, it seems that a majority of biblical scholars accept the argumentation and the conclusion offered in Gard Granerød's monograph on Genesis 14* from 2010 (Granerød 2010; Na'aman 2015; Na'aman 2016, p. 4; Lipschits et al. 2017, p. 264; Lipschits 2018, p. 197; Römer 2018, p. 212). ${ }^{6}$

Granerød's point of departure is that the biblical Abraham tradition, as many others have noted (Köckert 2017), seems to be of relatively late date compared to other patriarchal traditions. It was probably first after Judah's Babylonian crisis in the sixth century BCE that Abraham first had a "successful career" as the forbear of the people. The crisis resulted in the destruction of Jerusalem, its temple, and the deportation of the upper echelons of the Judaean society, often referred to as the Babylonian exile or the exilic period, even though such terminology is misleading (Granerød 2019).

Moreover, chapters 14-17 in Genesis seem to be a block of narratives working as a wedge between an assumedly more original and immediate connection between Genesis 13 and Genesis 18. From a redaction critical point of view, there is a potential continuation; Genesis 18: 1 appears to continue where Genesis 13: 18 ends:

So Abram moved his tent, and came and settled by the oaks of Mamre, which are at Hebron; and there he built an altar to the LORD. ... The LORD appeared to him [thus the Hebrew text; NRSV: Abram] by the oaks of Mamre, as he sat at the entrance of his tent in the heat of the day. (Gen 13: 18; 18: 1 NRSV [slightly changed])

Therefore, using the redaction critical method of subtraction, the block of Genesis 14-17 seems to be inserted into an earlier phase of the Abraham narratives' literary growth. Moreover, relying on the commonly accepted view that one can identify the so-called Priestly Source as a continuous narrative thread throughout the first books of the Pentateuch, we can identify Genesis 17 as a Priestly text within Genesis 14-17. Genesis 17 prescribes circumcision as a "sign of the covenant" between God and Abraham and his descendants. Like other Priestly texts, Genesis 17 is also concerned with chronological data relating to the patriarchs' age. The Priestly author of Genesis 17 was familiar with a tradition about Ishmael as Abraham's son (Gen 17: 18, 20, 23, 25-26). Therefore, we may infer that the Priestly author knew the story about the birth of Ishmael (Gen $16^{*}$, that is, the earlier, non-Priestly story which the Priestly author commented upon and expanded).

Within the block of Genesis 14-17, one of the opening phrases in Genesis 15 ("your reward shall be very great", Gen 15: 1) connects with Genesis 13: 14-15, a text of promise that belongs itself to the Priestly Source or that is even post-Priestly. Therefore, Genesis 15 is dependent upon Priestly material and later than the Priestly source.

None of the other texts within the Genesis 14-17 block seems dependent upon Genesis $14^{*}$ from a redaction critical perspective. ${ }^{7}$ This suggests that Genesis $14^{*}$ represents the latest addition to the Genesis 14-17 block, the textual block that itself breaks off a potential original continuation between Genesis 13: 18 and Genesis 18: 1.

\subsection{What Triggered the Composition of Genesis $14^{*}$ ?}

We have established a relatively late date of composition for Genesis $14^{*}$. Contrary to the view of those scholars who seek its background in a very ancient tradition (Westermann 1985, pp. 192-93; Emerton 1971; Schatz 1972, pp. 263-89, 309-24), we should consider it as 
post-Priestly, meaning that it belongs to the latest layers of the Abraham narratives' literary growth. What triggered the composition of Genesis $14^{*}$ ?

Granerød (2010, pp. 79-98) suggested that the author of Genesis $14^{*}$ was triggered by a desire to tighten up what he considered a Leerstelle ${ }^{8}$ in the text that immediately preceded it in Genesis 13: 14-18. In Genesis 13: 14-17, Yahweh appeared to Abram and commanded him to look at the land in all directions. In addition, he commanded the patriarch: "Rise up, walk through the length and the breadth of the land, for I will give it to you". (Gen 13: 17). However, the author of Genesis 14* saw the note in Gen 13: 18 about Abram's corresponding action ("So Abram moved his tent, and came and settled by the oaks of Mamre, which are at Hebron; and there he built an altar to the LORD", Gen 13: 18 NRSV) as only a partial fulfilment of Yahweh's command, at best. First, Genesis 13: 18 lacks a report of the actual event that is comparable to other texts where the patriarch fulfils Yahweh's command (e.g., Gen 12: 4a "So Abram went, as the LORD had told him ... "). Second, Abram's moving of his tent can hardly be understood as nearly comparable to the command to walk through the length and the breadth of the land. This has led Granerød to argue that the composition of Genesis $14^{*}$ is the result of literary creativity in late-biblical times. The author of Genesis $14^{*}$ was triggered by the Leerstelle after the command to walk through the land in Genesis 13: 17. By composing Genesis 14*, the author filled out this Leerstelle. There is an inner coherence between the ritual prescribed in the command in Genesis 13: 17 (which is similar to what later rabbinic terminology called a h̆ăzāqâ, a legal term for a particular mode of acquiring ownership or a means for proving ownership), and the actions that Genesis $14^{*}$ describe. In Genesis $14^{*}$, the invading coalition performs such a rite, thus jeopardising the land promised to Abram. However, at last, through Abram's pursuit through the land and final victory, the threat posed by the invading kings is nullified.

In his creative endeavour, the author of Genesis $14^{*}$ borrowed literary building blocks from earlier biblical texts and quasi-geographical information he probably received through interaction with, e.g., foreign diaspora communities in his vicinity (Granerød 2010, pp. 99-128). Three biblical texts or text groups crystallise as the author's sources. The Hebrew Bible's so-called historical books make up one type of source. Narratives from these books, especially from 1 Samuel 30 (David's alleged campaign against the Amalekites), provided the author with both style and narrative framework (Astour 1966; Stoltz and Breytenbach 2001). Moreover, the Table of Nations (Gen 10) seems to have been another important source (Granerød 2010, pp. 115-21). The author of Genesis 14* probably drew much of the geographical data from this text. Finally, another essential biblical source for the author is the wilderness wandering narrative (Deut 1-3; Num 10-21) (Driver 1905, p. 155; Astour 1966, p. 73; Granerød 2010, pp. 106-9). In this narrative, the author of Genesis $14^{*}$ found an itinerary that he inverted and turned into Chedorlaomer's campaign route. Besides, he found place names that he personalised and turned into people within the narrative of Genesis $14^{*}$.

However, whereas the author borrowed many of the names from the above mentioned biblical texts, he cannot have borrowed the names of the four invading kings from any biblical source. Granerød (2010, pp. 115-21) argues that the author borrowed the names from other peoples he was in contact with or had knowledge of. Ezra 4 illustrates the ethnographic and geographic horizon that one may expect that Judaeans had in the Persian and the early Hellenistic periods. Ezra 4 mentions, among the adversaries of the Judaeans, the "Persians", "people of Erech", and "Babylonia" (both of whom are associated with Shinar according to the Table of Nations; see Gen 10: 10), and "Elamites".

Nadav Na'aman (2015) picks up Granerød's lead concerning the question of what source the author of Genesis $14^{*}$ might have had. However, he broadens the question. $\mathrm{Na}^{\prime}$ aman is not only concerned with the names of the invading kings. He also focuses on the overall style of the campaign report, the combination of annalistic and narrative styles, the rapid movement of the plot and the shift of fronts, the abundance of names and dates, the decisive victory of the hero over his enemies, and the hero's restoration of peace in the 
land. Na'aman suggests that the author was acquainted with an oral version of Darius I's famous Bisitun trilingual inscription. The Persian king commissioned the inscription around $520 \mathrm{BCE}$ to commemorate his victories over his enemies. It is evident beyond doubt that the Persians dispersed versions of the inscription throughout the empire (Granerød 2013). By imitating the Persian king's literary-ideological image, the author of Genesis $14^{*}$ construed Abram as a remarkable, heroic figure. Na'aman himself articulates the conjectural nature of this intriguing theory. Only the names of the four invading kingdoms and Arioch's name might have been borrowed directly from Darius' list of peoples/lands. The fact that Genesis $14^{*}$ mentions four invading kingdoms reflects an ancient Near Eastern concept of the world's four quarters. For example, King Cyrus presents himself as "king of the four quadrants of the world" in line 20 in his famous Cyrus Cylinder. According to $\mathrm{Na}^{\prime} \mathrm{aman}$, the four kings represent the four quadrants of Hither Asia: Elam (east), Babylonia (south), Ellasar (north), and Goyim (west). As for the invading kings' names, Na'aman suggests that the author fitted to each kingdom a personal name that he borrowed from the language spoken in that land. Amraphel is probably a distorted pronunciation of the Babylonian name Hammurabi, and Tidal is probably the Hittite royal name Tudhalia, both as they would be pronounced in the oral tradition. Chedorlaomer is comprised of two Elamite name components, kutir/kudur and lagomar, both attested Elamite names (but never together except in Genesis $14^{*}$ ). Slightly more detailed reasoning causes $\mathrm{Na}^{\prime}$ aman to connect the personal name Arioch (according to $\mathrm{Na}^{\prime} \mathrm{aman}$, an Indo-European name) with the kingdom Ellasar, a kingdom that he argues was associated with Uratu/Armenia.

\subsection{Genesis 14*: A Narrative from the Persian or Early Hellenistic Period with Territorial Implications}

Above, the present study argues that Genesis $14^{*}$ represents a post-Priestly, relatively late, addition to the stories about the patriarchs. In terms of the absolute date, a post-Priestly date implies a date of composition in the Persian or early Hellenistic period. On the other hand, the Aramaic literary work known as the Genesis Apocryphon from Qumran (1QapGen ar) depends on Genesis 14. It offers an example of a creative rewriting of Genesis 14 and other parts of the Book of Genesis. The Genesis Apocryphon dates to the second century BCE (Machiela 2009, p. 142). Therefore, Genesis 14* must have been composed either in the fifth, fourth, third, or in the first half of the second century BCE. As for Judah's history, we know that these three and a half centuries cover the entire Persian period and the early Hellenistic period.

Throughout these centuries, there was no kingdom of Israel or Judah. In these centuries, Judah and the Judaeans were bereft of kings and governors of their own. Furthermore, Judah was incorporated as a province in the Persian Empire and later in the Seleucid Empire. With the Hasmonaean dynasty's arrival in the second century BCE, Judah, for a short while, partly regained limited independence as a kingdom within the Seleucid Empire. The Hasmonaean Kingdom even expanded its territory significantly into the Negev to the south of the Judaean heartland and the territories of Israel's former kingdom in the north.

The lack of king and territory in the Persian and Hellenistic periods did not refrain the Judaeans from engaging with theoretical theological and political issues with territorial implications. On the contrary, the delimitation of the land developed as a literary topos. The topos is evident in texts like Numbers 34, Joshua 13-19, and Ezekiel 47. Scholars debate the origin and exact relation between these texts that deal with the promised land's boundaries. Regardless of their origin and the question of any possible dependence between them, the literary context where they appear was not composed before the Persian Period (Numbers 34: Noth 1968, pp. 10, 248; Joshua 13-19: Ottosson 1991, pp. 105-32; Noort 1998, pp. 173-97; Römer 2007, pp. 89-90; Ezek 47: 13-23: Zimmerli 1969, pp. 109*-14*, 1202-19). Moreover, 1 Chronicles 2-8, written in the late Persian or early Hellenistic period building upon probably both oral and written sources (Person 2010, pp. 78-92), demonstrates an interest in associating territorial lots with the twelve sons of the patriarch Jacob, who is also called Israel and is the eponymous ancestor of the people of Israel. 
The territorial implications of the campaign headed by the Elamite king and Abram's subsequent actions become even more evident in the light of other texts with territorial implications. Judaeans who were living when Genesis $14^{*}$ was created met ideas about the former greatness of the land like those expressed in the texts previously mentioned. Genesis $14^{*}$ contains important keywords about boundary descriptions and itineraries that remind the readers of such (biblical) texts.

The first example in Genesis $14^{*}$ that resembles other biblical texts with territorial implications is the chapter's mention of Zoar and Dan. These two place names work as geographical extremes that "envelope" Abram's territory in Genesis $14^{*}$. The chapter includes the city of Zoar as part of the Pentapolis (Gen 14: 2). Within the chapter's literary context, Zoar's location is near the Dead Sea (Gen 14: 3). Moreover, in Genesis 13: 10, Zoar is the most remote place on the Plain of Jordan.

On the other hand, Genesis 14: 14 claims that Dan was the place Abram's men defeated Chedorlaomer's coalition (and from whence Abram's army pursued the invaders to Hobah, north of Damascus). Dan represents an anachronism in the patriarchal narratives when read within the context of the Hebrew Bible canon. According to Judges 18: 29, the Danites fought against the city Laish, took possession of it, and called it Dan after their ancestor Dan. This ancestor was born to Jacob after the death of Abraham (see Gen 30: 6). In light of the general geographical interest the author of Genesis $14^{*}$ displays, he probably referred to this particular city as the traditional northern border of Israel. Narratives set in the early monarchy period (e.g., 1 Sam 3: 20; 2 Sam 3: 10; 17: 11; 24: 2, 15; 1 Kgs 4: 25) use the formula "from Dan to Beer-sheba" as representations of the conventional northern and southern boundaries (Sæbø 1974; Fritz 2000). In narratives set in the period of the divided monarchy (after King Solomon and before the Babylonian crisis), Dan continues to mark the northern boundary of Israel (the Northern Kingdom, 1 Kgs 12: 29-30; 2 Kgs 10: 29).

In the Hebrew Bible, Dan and Zoar appear together in the same context in two texts only: Genesis $14^{*}$ and Deuteronomy 34. Deuteronomy 34 belongs to one of the latest-if not the latest-editorial frameworks around the Book of Deuteronomy's core (Blenkinsopp 1992, pp. 229-31; Nelson 2002, pp. 8, 393-97; Lundbom 2013, pp. 16, 18, 25, 90-92). In Deuteronomy 34: 1-3, Zoar and Dan mark the land's southern and northern borders. The setting of Deuteronomy 34: 1-3 resembles Genesis 13: 14-17 (discussed above), even though both the narrative setting and the person Yahweh addresses differ. In Deuteronomy 34, Moses has walked up to Mount Nebo. On Mount Nebo, Yahweh showed Moses the land:

[A]nd the LORD showed him the whole land: Gilead as far as Dan, all Naphtali, the land of Ephraim and Manasseh, all the land of Judah as far as the Western Sea, the Negeb, and the Plain — that is, the valley of Jericho, the city of palm trees-as far as Zoar. (Deut 34: 1b-3 NRSV, my emphasis)

Therefore, in light of Deuteronomy 34, it is likely that the reference in Genesis $14^{*}$ to Zoar and Dan alludes to the land's southern and a northern border. Throughout the chapter, there is a movement through the length and the breadth of the land. However, whereas the invading kings take the first steps (near Zoar), Abram completes the walk through the land (in Dan).

The second instance in Genesis $14^{*}$ that resembles other biblical texts with territorial implications emerges from reading the entire chapter as a geographical text based on campaign itineraries (cf. Aharoni and Rainey 1979, pp. 83-92, 140-42; Alexander 1992, p. 986). The chapter plots a map of the land where Abram is de facto in power. By defeating Chedorlaomer and his allies (Gen 14: 1-12), Abram succeeds as master and controls their campaign's fruits (cf. Kallai 1998, p. 239). Also, Abram appears as master over the territories that he takes control over when he pursues and defeats Chedorlaomer (Gen 14: 13-17, 21-24). The land plotted in the narrative and eventually controlled by Abram resembles the extent of David's empire as presented in the catalogue of his victories in 2 Sam 8: 1-15. Apart from the Philistine territory mentioned in 2 Samuel 8: 1, the territories of the ethnic groups mentioned in the catalogue of David's victories are embraced by the itineraries of Chedorlaomer's coalition (Gen 14: 5-7) and Abram (Gen 14: 13-15) 
respectively. Therefore, the author of Genesis $14^{*}$ probably borrowed from the tradition about King David's empire's magnitude-either identical with that reflected in 2 Samuel 8: 1-15 or a tradition similar to it-when he composed his late text about Abram's war.

On the one hand, it is ironic that Genesis $14^{*}$ is about Abram's involvement in the international political scene and control of a vast territory. After all, it was composed when Judah was bereft of kings and governors of its own. Instead, it was ruled as a province within an empire-be it the Persian Empire or the Seleucid Empire. However, on the other hand, it is in such times that the Judaeans produced much of their literature in which they recast themselves as the legitimate owner of the land and as having heroic ancestors and spiritual forefathers, be it Abram, Moses, or David. Thus, much of the biblical literature and definitely Genesis $14^{*}$ can be approached from a postcolonial perspective as an example of a discourse of resistance (cf. Perdue et al. 2015, p. 32; Yee 2010, pp. 193-209). In composing Genesis $14^{*}$, the colonised imitated their colonisers in portraying a legendary ancestor as a triumphant and just victor in a war against the early representatives of the colonisers (cf. Bhabha 2004, pp. 121-31). One can hardly avoid asking what implications Judah's status as a province in the Persian and the Seleucid Empire had for the author who wrote Genesis $14^{*}$ and the narrative's first readers (cf. Perdue et al. 2015, pp. 107-28, 129-215). In this narrative, "Abram the Hebrew" - which we will see probably translates as "Abram the one from Eber-nāri (Beyond-the-River)"—fights back!

\subsection{Excursus: "Hobah, North of Damascus" (Gen 14: 15)}

The dependence of Genesis $14^{*}$ upon the catalogue of David's victories (2 Sam 8: 1-15) in plotting the land controlled by Abram can bring us closer to an explanation of a topographical crux. According to Genesis 14: 14-15, Abram defeated Chedorlaomer's coalition in Dan and "routed them and pursued them to Hobah, north of Damascus". Hobah is unattested elsewhere in the Hebrew Bible. The biblical text's early reception history demonstrates that ancient translators disagreed in identifying (and locating) it. The Greek Septuagint translation merely transliterates the name as $X \omega \beta \alpha$. The rewritten version of Genesis $14^{*}$ in the Genesis Apocryphon from Qumran reads hlbwn (Helbon, 1QapGen ar XXII 10). In modern scholarship, there have been several proposed identifications of Hobah (Thompson 1992). However, even there is no certainty, the identification that seems to dominate is that Hobah is "(the land of) Ub/pe" or "Api", found in the Execration Texts and the Amarna inscriptions from the second millennium BCE Egypt (e.g., Schatz 1972, pp. 185-86; Köhler et al. 2000, p. 295, s.v. hôbâ). This land roughly embraced modern Syria and Lebanon (Pitard 1992). However, it is difficult to explain why biblical Hobah is said to be north of Damascus because the latter city should instead be included in the land of $U b / p e$. The Genesis Apocryphon's suggestion Helbon is probably identical to the village Helbun in the Beqaa Valley. In light of this stalemate and in light of the thesis that Abram's territory in Genesis $14^{*}$ reflects the catalogue of David's victories in 2 Samuel 8: 1-15, the present study suggests that we should seek the solution as to the identity of Hobah in a scribal error. Provided that the author of Genesis $14^{*}$ was dependent upon 2 Samuel 8: 15, it is noteworthy what 2 Samuel 8: 3, 5 says: "David also struck down King Hadadezer son of Rehob of Zobah.... When the Arameans of Damascus came to help King Hadadezer of Zobah, David killed twenty-two thousand men of the Arameans". (NRSV, my emphasis). In Hebrew, the place name Zobah (șobâ) is suspiciously similar to Hobah (hobâ). The Hebrew letters he and tsade are not very similar, neither in the so-called Paleo-Hebrew alphabet nor in the square Aramaic alphabet that Judaeans/Jews began to use in the Persian, Hellenistic, and Roman Periods. Still, it remains likely that there probably was assonance between Hobah and Zobah when Genesis $14^{*}$ was composed. Also, in both Genesis $14^{*}$ and 2 Samuel 8, Hobah/Zobah is associated with Damascus. Therefore, the present study proposes that Hobah in Genesis 14: 15 is a corrupted rendition of Zobah in 2 Samuel 8: 3, 5. Again, the territory that Abram controlled, according to Genesis $14^{*}$, is modelled upon David's empire in 2 Samuel 8: 1-15. 


\section{The Reference and Perception of Elam and the Other Friends and Foes of Abram}

Above, we saw that Genesis $14^{*}$ is a narrative with territorial implications, written in the Persian or early Hellenistic period. This section will discuss to whom or what the names in Genesis $14^{*}$ refer. Methodologically speaking, the question of an ancient author's intention is elusive and difficult to control. It is probably safer to approximate the first readers' perceptions of the names. The (author-intended) reference and the (reader-centred) perception of the geographical names are at stake in this section.

The references to and perceptions of "Persia" in the Hebrew Bible are not limited to references to Persian kings and the life at Persian royal courts, such as those we can find in 2 Chronicles 36, Esther, Nehemiah, Daniel 6; 8; 10; 11, or the prophetic oracle concerning King Cyrus in Isaiah 45. While some of the biblical texts refer to or reflect a perception of Persia in a positive way, other texts are more reluctant. Ezra 4: 6-16 may perhaps hint at Judaean participation in a revolt against the Persian Great King. ${ }^{9}$ Moreover, according to a lengthy prayer of repentance (Neh 9: 5-37), the Levites describe Judaeans in the Persian period as "slaves": "Here we are, slaves to this day-slaves in the land that you gave to our ancestors to enjoy its fruit and its good gifts" (Neh 9: 36 NRSV). ${ }^{10}$ This section will argue that in Genesis $14^{*}$ and its literary context, there are several references to the Persian Empire and names associated with Persia:

- The land Genesis 15 claims that Yahweh would give to the patriarch corresponds to the region Eber-nāri (Beyond-the-River, or Transeuphratia; in Aramaic and Hebrew (br nhrh).

- Within the context of Genesis $14^{*}$, the description of Abram as hā ibrî (traditionally translated "the Hebrew", Gen 14: 13) characterises Abram as a person from the region Eber-nāri.

- In the Hellenistic and Hellenistic periods, Judaeans could associate the names Chedorlaomer and Elam with Persia.

The following discussion aims at substantiating these suggestions. Also, it will explore the possibility that Judaeans/Jews in antiquity associated Lot and the five Canaanite kings alliance with neighbouring ethnic groups.

\subsection{Eber-nāri (Beyond-the-River)}

Our knowledge of the details of the administrative units introduced by the Persians is much more approximate and based on later, secondary, even tertiary, sources than one often thinks (Wiesehöfer 2001, pp. 59-62). Nevertheless, there is no doubt about the existence of an administrative unit called Eber-nāri (Beyond-the-River) in the Persian period. To begin with, it was part of the immense satrapy Babylon and Eber-nāri, the two regions that together once formed the Neo-Babylonian Empire. Later in the Persian period, Babylon and Eber-nāri were separated and established as satrapies of equivalent status (Stolper 1989, p. 292; Briant 2002, pp. 543-44, 578; Kuhrt 2020, p. 126). At the end of the Persian period, Eber-nāri appears to have been a satrapy together with Cilicia (Briant 2002, pp. 709, 713). Eber-nāri encompassed the region west of the Euphrates, and we can trace that name back to the Assyrian period (Berner 2015b, p. 679). Neo-Assyrian, Neo-Babylonian, and Late-Babylonian inscriptions use the name. Moreover, Ezra and Nehemiah refer to Beyondthe-River and its governors (Ezra 4: 10-11, 16-17, 20; 5: 3, 6; 6: 6, 8, 31; 7: 21, 25; 8: 36; Neh 2: 7,$9 ; 3: 7)$.

The boundaries of Beyond-the-River can be ascertained through deduction. On the one hand, the region's very name suggests that a river constituted one of its boundaries. This river was the Euphrates. On the other hand, Egypt constituted a separate satrapy (Briant 2002, pp. 472-84; Tuplin 2020, pp. 38-45). Literary sources from the fifth century, for example, refer to the Persian officials Pherendates and Arshama as Egypt's leaders. Strictly speaking, the sources from Egypt never mention the title "satrap". However, the sources written in demotic Egyptian script refer to Pherendates as the one "to whom Egypt is entrusted" (Granerød 2016, p. 304, n. 144). Therefore, Beyond-the-River was west of the Euphrates and east of Egypt. It is to this region that Genesis 15: 18 refers. We can assume 
that readers in antiquity also understood the delimitation "from the river ... to the river" in Genesis 15: 18 in this way.

\subsection{Abram the One from Beyond-the-River}

According to the traditional translations, Genesis 14: 13 presents Abram as "the Hebrew". Strictly speaking, the Hebrew text reads 'abrām hāibrî. Traditionally, one has explained the word 'ibri as a name with gentilic value. In the literary universe of the patriarchal narratives, one can explain 'ibrî as a derivation based upon the personal name, Eber. According to the partly geographical, partly ethnographic text called the Table of Nations (Gen 10), Eber was one of the forefathers of Abra(ha)m. Understood in this way, the phrase "Abram the 'ibri" means something like "Abram the Eberite" or "the descendant of Eber".

In the Hebrew Bible, the word 'ibrî accumulates in the Joseph story (Gen 37-50) and the exodus narrative (Exod 1-15). As Christoph Berner (2015b, p. 676) puts it, 'ibrî is always applied to the proto-Israelites, "either by themselves (Gen 40: 15; Exod 1: 19; 2: 7), by the Egyptians (Gen 39: 14, 17; 41: 12; Exod 1: 16 [1: 22 LXX]; 2: 6), or by the narrator (Gen 43: 32; Exod 1: 15; 2: 11, 13)". Also, in 1 Samuel 4; 13-14, the word 'ibrî occurs as a designation of the Israelites, mostly vis-à-vis the Philistines. Berner argues that the usage of the word peaks in the last stages of the Pentateuch's and 1 Samuel's redaction history. Many biblical scholars see the development of 1 Samuel as part of the development of the so-called Deuteronomistic History, that is, the continuous history of Israel and Judah we find in Joshua, Judges, 1-2 Samuel, and 1-2 Kings (Kratz 2005, pp. 170-86; Römer 2007, pp. 90-97). However, the situation is more complicated in the laws concerning an 'ibrî slave (Exod 21: 2; Deut 15: 12, cf. Jer 34: 9, 14). Nevertheless, Berner demonstrates that none of the laws concerning an 'ibrî slave requires an early date. In most cases, one can argue for a late origin of the texts using the word 'ibrî.

It proves unnecessary and irrelevant to seek a possible historical and etymological relationship between the biblical word 'ibrî and the term hapiru/apiru (thus, e.g., Dozeman 2009, p. 76; Meyers 2005, pp. 36-37 concerning Exod 1: 15; for a summary of earlier research on hapiruapiru/'apiru and the sometimes suggested relationship to ibrî, see Lemche 1992a, 1992b). Documents from the second millennium BCE use the latter term to describe a group or class of non-sedentary peoples, pirates, or plunderers (Berner 2015b, p. 678). There is a chronological and semantic gap between hapiru/apiru on the one hand and the biblical 'ibrî on the other. Therefore, the proposal of Derek R. G. Beattie and Philip Davies is likely: the biblical word 'ibrî means an inhabitant of the area known as Eber-nāri (Beyond-the-River; Aramaic and Hebrew: ' $b r$ nhrh). The Biblical Hebrew word ibrî is short for a person coming from the other side of the Euphrates, a "Transite" (Beattie and Davies 2011, p. 82) or "one from across (the river)" (Berner 2015b, p. 679). Etymologically, the Hebrew word 'ibrî is a derivation of the Semitic word 'éber, "one of two opposing sides" etc., used in the satrapy name Eber-nāri (Köhler et al. 2000, pp. 781-82, s.v. 'ēber I).

This understanding fits well with the portrayal of Abram in the context of Genesis $14^{*}$. Vis-à-vis the four invading kings headed by King Chedorlaomer of Elam, Abram is the protagonist who acts as the trans-river individual who incorporates the peoples from Beyond-the-River.

\subsection{Chedorlaomer, Elam and Persia}

In the Persian and Hellenistic periods, Judaeans associated the names Chedorlaomer and Elam with Persia. In Judaean literature written or edited in these periods, one could refer to the concept of Persia and Persians through multiple terms. The terms Media/Medes and Elam/Elamites/Susa especially came into play. In some texts, it seems that these names could work as alternatives for Persia. In other texts, they worked as terms that overlapped with Persia. ${ }^{11}$ Some biblical texts seem to let Persia, Media, or Elam—or a combination of them-stand for the political power(s) that put an end to and succeeded the Babylonian Empire. 
The semantic flux between and conceptual blending of Persia and Elam (which is most relevant in our case) is visible in different kinds of texts. In the so-called Cyrus Cylinder, the famous king addressed himself as "King of Anshan", using a traditional Elamite royal title (Allen 2005, p. 24; Kuhrt 2007, pp. 47, 73). However, other sources remember him as "King of Persia". This is the case in, e.g., the Nabonidus Chronicle ("Cyrus, king of Anshan", and "Cyrus, king of Parsu", cf. Kuhrt 2007, pp. 50-51) and biblical texts (2 Chr 36: 22-23; Ezra 1: 1-2, 8; 4: 3, 5; 6: 14, 29; Dan 10: 1).

Moreover, the so-called Chedorlaomer Texts (also known as the Spartoli Tablets) shed light on how Elam could be associated with Persia in antiquity. The tablets were made in the Seleucid (Hellenistic) period by scholars who still wrote (and copied) documents in Akkadian. The tablets date to 142 BCE (Na'aman 2015, p. 76). Some scholars argue they were based upon documents from the Persian period or even earlier periods, but this is contested (Foster 2005, p. 369; Na'aman 2015, p. 76). The tablets account of an Elamite invasion, the destruction of Nippur and Babylon, and the sacrilege of the temple Esagila. They are fragmented and partly unintelligible but identify one of the protagonists as KudurNahhunte, King of Elam. Regardless of the tablets' historicity, the scribe who copied or composed them did so a long time after the alleged events took place. A possible rationale for this may have been that he wanted to highlight the analogy between the Elamite King and "the rapacious post-Darius Persian monarchs, in addition to their historical interest as pertaining to a turning-point in Babylonian history" (Foster 2005, p. 369). In any event, we can understand the so-called Chedorlaomer Texts as anti-Persian literature, either from the Seleucid (Hellenistic) period or from an earlier time. The so-called Chedorlaomer Texts used the Elamite King Kudur-Nahhunte as a symbol of evil coming from the east like the Persians once had done. ${ }^{12}$

Furthermore, the ancient Greek translation of the Book of Jeremiah probably connects the oracle against Elam with the Parthian Kingdom. On the one hand, the Parthians succeeded the (Hellenistic) Seleucid Empire in the east. On the other hand, the Parthians saw themselves as the heirs of the Persian Achaemenid Empire. William McKane (1996, p. 1248) suggests that the leading position of Elam in the Septuagint's version of Jeremiah's oracles against the foreign nations implies that the translators equated Elam with Persia. The Greek version of the oracle in Jeremiah 25: 14-26: 1 LXX (corresponding to Jeremiah 49: 34-39 in the Hebrew, Masoretic text) has eliminated some of the historical notes found in the Hebrew text (cf. Jer 49: 34b). The Hebrew text's historical notes connect the oracle against Elam to the Neo-Babylonian expansion in the seventh and sixth centuries BCE. However, the translators behind the Greek Septuagint version aimed their text at the Judaean/Jewish diaspora in Egypt of the Ptolemaic period. For the translators and intended audience of the Greek text, Elam was part of the Parthian Kingdom. They probably equated Elam with Parthia. Therefore, for them, Elam was not in the distant past but a key power of their own time (Dubovský 2018, p. 36). Parthia was more important than Egypt and Babylonia, the two former superpowers that had become provinces of the Persian, and later, the Ptolemaic and the Seleucid Empires. Consequently, the Septuagint translators living in Ptolemaic Egypt probably saw Jeremiah's prophecy of the fall of Elam as an indirect prophecy of the Parthian kingdom's fall; that is, the kingdom that to some extent was regarded as the continuation of the Persian Achaemenid Empire. ${ }^{13}$

Eventually, writing from the first century CE perspective, the Jewish historian Josephus articulated the relationship between Persia and Elam. According to Josephus, the Elymaeans are the Persians' ancestors (Ant. 1.143). Elymais is the Greek rendering of Elam (Salaris 2019).

\subsection{Lot, the Pentapolis Kings, and Judah's Neighbours in the Persian and Hellenistic Periods}

Judah had no political independence and no indigenous king when Genesis $14^{*}$ was composed. On the contrary, it was a tiny part of the Persian or the Seleucid Empire. The scribes who composed Genesis $14^{*}$ were Judaeans who construed a fictive historical account with their ancestor Abram as the protagonist and Elam as the main antagonist. 
Through Abram's interaction with the narrative characters in Genesis $14^{*}$, the author contributed to the ongoing construction of a Judaean/Jewish identity. Moreover, the author contributed with ideas about the ideal boundaries for the land. Above, we have seen that Abram the 'ibrî, understood as "the one from Beyond-the-River", defeated the coalition headed by Elam, pursued it to "Hobah, north of Damascus" (Gen 14: 15), and thereby defined the territory he controlled. (And in Gen 15: 18, Abram's patron god, Yahweh, even granted the patriarch the title to "this land, from the river of Egypt to the great river, the river Euphrates".) The victory of Abram the 'ibrî in Genesis 14*, Yahweh's gift of land in Genesis 15 ("from river ... to river"), as well as the names Chedorlaomer and Elam evoked associations with Persia and the administrative unit Beyond-the-River.

However, Genesis $14^{*}$ also mentions other names. One person stands out since his involuntary involvement in the events triggered Abram: Lot. Earlier in the narrative context of Genesis $14^{*}$, Abram and his relative Lot had separated in a more or less friendly way (Gen 13: 5-13). The result was that Abram settled in the land of Canaan (Gen 13: 12), while Lot journeyed eastward (Gen 13: 10-11).

The personal name Lot and the toponyms of Genesis $14^{*}$ probably had ethnographic, territorial, and political associations within the conceptual world of Judaeans of the Persian and Hellenistic periods. According to the Hebrew Bible, Lot was the ancestor of the Moabites and the Ammonites. The patriarchal narratives present him as a relative of Abram (according to Genesis 12: 5; 14: 12: "the son of his brother", according to Genesis 14: 16: "brother"). Later in the patriarchal narratives, the story of the judgment of Sodom and Gomorrah (Gen 18-19) claims that Lot escaped from Sodom and Gomorrah, via Zoar, and settled "in the hills with his two daughters" (Gen 19: 30). According to the following episode, his two daughters realised that they would end up as unmarried women. Therefore, they made their father Lot drunk and slept with him. The incestuous intercourses resulted in two sons: Moab, "the ancestor of the Moabites to this day", and Ben-ammi, "the ancestor of the Ammonites to this day" (Gen 19: 37-38). Therefore, when we read Genesis $14^{*}$ as a late narrative added in the last stage of the Abraham narratives' literary growth, we can assume its author presupposed the ethnographic and territorial knowledge inscribed in Genesis 19. In this perspective, Abram's benevolent-and superior-actions vis-à-vis Lot in Genesis $14^{*}$ implied that the patriarch's position surpassed that of Lot's descendants, the Moabites and the Ammonites.

Many of the names in the campaign route of Chedorlaomer's alliance (Gen 14: 5-7) connect the narrative to Moab and Ammon, but also Edom/Idumaea, particularly if we accept the premise that the author was dependent upon the wilderness wandering narrative (Deut 1-3; Num 10-21, see Section 2.2 above, and Granerød 2010, pp. 107-9). Deut 2: 20 associates "the Rephaim" (cf. Gen 14: 5) with the Ammonites, and Deut 2: 10 associates "the Emim" (cf. Gen 14: 5) with Moab. Moreover, additional names in the campaign route- "the Horites in the hill country of Seir as far as El-paran", "En-mishpat (that is, Kadesh)", "the country of the Amalekites", and "the Amorites in Hazazon-tamar" (Gen 14: 6-7) - connect the narrative to Edom and its successor Idumaea. Deut 2: 22 associates "the Horites" with the descendants of Esau, the legendary ancestor of Edom. The otherwise unknown "El-paran" (Gen 14: 6) may play on the places "Elath" and "the wilderness of Paran" from the wilderness wandering narrative (Num 10: 12; 12: 16; 13: 13, 26; Deut 1: 1; 2: 8). The place-name "En-mishpat (that is, Kadesh)" (Gen 14: 6) probably reflects the Kadesh-barnea in Deut 1: 19-20.

The author and readers of Genesis $14^{*}$ in the Persian or Hellenistic period, who found Genesis $14^{*}$ as the literary continuation of Genesis 13 , might have associated the regions to the east, southeast, and south of Judah with Edom and its successor Idumaea. This possible association may have been supported by the author's and the readers' already existing knowledge of the narrative cycle about the patriarch Isaac and his twin sons, Jacob and Esau (Gen 25: 19-36: 43). The core of this narrative cycle belongs to the earliest components of the patriarchal narratives (Kratz 2005, pp. 260-74; for a discussion of the identification of Edom with Esau from Seir, see Dicou 1994, pp. 116-54). The narratives about Esau make 
Mount Seir his (and thus Edom's) home (Gen [25: 25; 27: 39;] 32: 3; 33: 14, 16, cf. Ezek 35: 1-9). Also, the genealogy of Esau in Genesis 36 (which is a so-called Priestly, and therefore relatively late, layer in the Pentateuch's compositional history, cf. Kratz 2005, pp. 231, 238, 241) connects Esau/Edom with the Seir region (vv. 1-2, 6-9, 32).

Moreover, the author's and the readers' knowledge of the catalogue of David's victories in 2 Samuel 8: 1-15 may have further supported the association with Edom and Idumaea. As we saw above, Genesis $14^{*}$ plots a map of Abram's land similar to King David's territory according to 2 Samuel 8: 1-15. The author likely had access to a text similar to the catalogue in 2 Samuel 8: 1-15. According to 2 Samuel 8: 13-14, David subdued Edom, and the Edomites became David's servants. ${ }^{14} 2$ Samuel 8: 13 names the battlefield where David defeated the Edomites "the Valley of Salt". The author and earliest readers of Genesis 14* may have associated "the Salt Sea" (Gen 14: 3) with the place where David conquered Edom.

Eventually, we cannot rule out that the author of Genesis $14^{*}$ knew some of the primarily anti-Edomite stances in many prophetic texts (cf. Dicou 1994, pp. 20-114). However, there are no traces to it in the narrative.

In the Neo-Assyrian and Neo-Babylonian periods (Iron Age II), the Kingdom of Edom existed with Bozrah as the primary urban centre (Bartlett 1989, pp. 115-46; Edelman 1995; Knauf-Belleri 1995; Levin 2020). It controlled copper mines and the lucrative trade routes from southern Arabia ("the King's Highway") to the east of the Arabah Valley in southern Transjordan. Meanwhile, it also controlled the Arabah Valley and the Negev. In the Judaean epigraphic source known as Arad 40 (from the last half of the seventh century BCE), a military commander reports to Judah's king about "the evil" the Edomites had done. Another military letter is the somewhat later document Arad 24. The document contains commands about the regrouping of soldiers to protect the city Ramat-Negev, apparently against Edom (Lindenberger 2003, pp. 118-20, text nos 51 and 53).

The Kingdom of Edom was probably one of the last Syro-Canaanite kingdoms overturned by the Babylonians in the mid-sixth century BCE (Lindsay 1976; Bartlett 1982; Crowell 2007). However, in the Persian and Hellenistic period, the province of Idumaea represented a continuation of the Iron Age II Kingdom of Edom. Yigal Levin calls Idumaea "the new Edom" (Levin 2020, pp. 3-4). One can see the continuation in the name and in the fact that the god Qôs/Qaws continued to be the important patron god of Idumaeans, as he once seems to have been for the former kings of Edom (Vriezen 1965; Knauf 1984; Bartlett 1982; Dearman 1995; Knauf 1999; Kelley 2009; Cornell 2020; cf. Porten and Yardeni 2014-2020). However, the province of Idumaea underwent a parallel shift compared to Edom in the Iron Age II (Edelman 1995). In the Persian and Hellenistic period, the successor of Edom expanded and moved westward into the Negev, and Arad and Beer-sheba became leading cities. By the time of the Hellenistic period, the name Idumaea was used for the region south of Judah and west of the Arabah (Levin 2020, pp. 4-6).

We can speculate: Did the fictional narrative about Abram's de facto control of the region Eber-nāri (Beyond-the-River) and the kings therein resonate with the Judaean/Jewish, nationalistic enterprises at the time of the Hasmonaean dynasty in the second half of the second century BCE, like, e.g., John Hyrcanus' conquest of Idumaea in the Negev, south of Judah (cf. Josephus, Antiquitates 13: 257; Grabbe 1992, pp. 300, 328-331)? The exact identifications that a Judaean/Jewish reader in antiquity may have made of the names in Genesis $14^{*}$ will remain elusive. Nevertheless, we can assume that a Judaean/Jewish reader of Genesis $14^{*}$ in the Persian and Hellenistic periods would understand the story about the patriarch's de facto control of territories in the past as relevant for the present situation.

\section{Genesis 14*, Anthony D. Smith's Theory of Ethnic Community, and Postcolonial Theory}

The author of Genesis $14^{*}$, working in the Persian or Hellenistic period, created a fictive narrative about the patriarch. The resultant narrative was immersed with the names of peoples and regions. For Judaean/Jewish readers in antiquity, the narrative probably 
had territorial implications. It portrayed Abra(ha)m as the one from Beyond-the-River who defeated the invading coalition lead by King Chedorlaomer of Elam. Also, it portrayed the patriarch as one whom de facto controlled vast territories through his actions. In what follows, there are three aims. The first aim is to briefly present the historical sociologist Anthony D. Smith's theory of ethnic community (ethnie). The second aim is to show that reading Genesis $14^{*}$ (and its narrative context) through the lens of his theory advances our understanding of how the text in antiquity may have contributed to constructing and maintaining a Judaean/Jewish ethnic identity. The third aim is to hint at how elements of postcolonial theory can enrich a historically oriented and sociologically informed reading of Genesis $14^{*}$.

Smith articulated his theory on ethnic community most pointedly in his monograph from 1986 (Smith 1986; Hutchinson and Smith 1996). He claims that we can trace the idea of ethnicity to the pre-modern ages; it is not a modern invention. Moreover, ethnic groups, which Smith refers to using the French term ethnie, are defined through culture, not biology. He argues that there are six chief features or dimensions distinguishing an ethnie from other collectivities (e.g., class, religious communities, and territorial polities): (i) a collective name, (ii) a common myth of descent, (iii) a shared history, (iv) a distinct shared culture, (v) an association with a specific territory, and (vi) a sense of solidarity (Smith 1986, pp. 22-31). According to Smith, every ethnie has concepts and strategies for maintaining its uniqueness. The term ethnocentrism subsumes such strategies. Ethnocentrism, characterised by a genealogical and particularistic world-outlook, is the normal condition for every ethnie. Smith argues that both ethnocentrism and the closely related concept of ethnicism include movements of ethnic resistance and renewal. In antiquity, ethnicism manifested in three broad aims: territorial restoration, genealogical restoration, and cultural renewal. As per Smith, ethnicism is defensive and restorative. It identifies a double threat: internal divisions and decay on the one hand and external challenges and influences on the other. Threats can take several forms: military threats, socio-economic challenges, or cultural contact. An ethnie typically has a constitutive myth (Smith: a mythomoteur) that gives it sense and purpose. This constitutive myth can be dynastic (concerning the king's unique position) or communal (concerning the ethnic group's particular position).

Bereft of kings and governors of their own, the Judaeans/Jews of the Persian and Hellenistic periods began to evolve "a communal and sacred mythomoteur which was subsequently diffused through the Synagogue both in Judea and the diaspora" (Smith 1986, p. 64). Their communal constitutive myth stressed the early patriarchs and the genealogies.

The present study will argue that we can see Genesis $14^{*}$ as an example of a (late) Judaean/Jewish constitutive myth, in which the ancestor Abram, the one from Beyond-theRiver, plays the leading role in demarcating himself from King Chedorlaomer of Elam's alliance and his Canaanite neighbours. We can identify several of Smith's dimensions of ethnie in Genesis $14^{*}$ and its narrative context.

First, Genesis $14^{*}$ presents Abram with a collective name, hā ibrî. Traditionally, this has been understood as a gentilic and translated as "the Hebrew". Above, the present article argued that Derek R. G. Beattie and Philip Davies are probably correct in connecting the word 'ibrî to the region Eber-nāri. In sources from antiquity, the word 'ibrî appears as a synonym to "Judaean/Jew". However, at the same time, in Genesis $14^{*}$ 'ibrî has a precise meaning defined by narrative context. Judaeans/Jews in antiquity who identified with Abram the 'ibrî found in him the ancestor of the peoples living in Beyond-the-River. In the mythical yet constitutive past, Abram the 'ibrî contrasted invaders (such as the King of Elam) and other "Others" (such as the Canaanite neighbours) alike.

Second, like the rest of the patriarchal stories (Genesis $12-36$ ), Genesis $14^{*}$ reflects a myth of descent. Influential circles among the Judaeans/Jews of the Persian and Hellenistic periods gradually started seeing themselves as the true Israel (cf. Ezra 4: 1-4; 6: 21; 9: 2) and envisioned the return from the Babylonian Diaspora and the recovery of the land as a new Exodus and conquest of the Promised Land (cf. Ezek 11: 14-19; 36: 8-12; Isa 41: 17-20; 43: 14-21; 49: 9-12; Jer 32: 42-44; Yee 2010, pp. 227-28). The name Israel 
stems from the patriarch Jacob, who was renamed Israel (Gen 32: 28; 35: 9), and whose grandfather was Abram, and whose forefather again was Eber (Hebrew: 'éber), according to the so-called Table of Nations (Gen 10: 24-25; 11: 14-17). The Table of Nations presents itself as the genealogy of Noah's offspring, the one who survived the Flood and started a new chapter in the history of humankind. With seventy names (ethnonyms and toponyms), the Table of Nations is a geographical work that connected all known nations and their home countries into a single, coherent genealogy. The genealogy was structured based on Noah's three sons Shem, Ham, Japheth, and their respective offspring. When we read the patriarchal stories synchronically, Gen 14: 13 is the first attestation of 'ibrî used as a gentilic designation. In other words, a Judaean/Jew who identified Abram the 'ibrî (cf. Gen 14: 13) as his ancestor could delineate his/her relationship to the other nations in the world in general (through Eber, cf. Gen 10: 24-25; 11: 14-17), and to the region Beyond-the-River in particular (through Abram the 'ibrî, in the meaning "the one from Beyond-the-River).

Third, like the rest of the patriarchal stories, Genesis $14^{*}$ reflects an association with a specific territory. The patriarchal stories cursorily call it Canaan or merely the land Yahweh will give/has given the patriarchs. Genesis $14^{*}$ distinguishes itself in that it narratively delimits the land's boundaries through Abram's actions. Through his actions, Abram the 'ibrî takes control of a territory having an extent corresponding to the administrative unit Beyond-the-River, and King David's empire (cf. 2 Sam 8: 1-15).

Fourth, the narrative in Genesis $14^{*}$ lets Abram the Hebrew express a sense of solidarity with his Canaanite neighbours through his actions. Abram wages war against the invaders, releases the prisoners of war and returns the booty to the owners.

Genesis $14^{*}$ was composed when the Judaeans/Jews had fresh experiences with being colonised and part of an empire. If we approach the late text from the perspective of postcolonial theory, the story about Abram's war assumes characteristics of a discourse of resistance. If the present study is correct in dating the composition of Genesis $14^{*}$ to the Persian or early Hellenistic period, the chapter seemingly gives the subaltern or the periphery within an imperial context a distinct voice. The self-perception of the Judaeans/Jews telescoped onto the patriarch Abram, the one from Beyond-the-River; they articulated their construed self-understanding in and through Abram's interaction with other groups. One such group of "Others" was the alliance lead by King Chedorlaomer of Elam, who the Judaeans/Jews in antiquity probably could see as representing the Persian Empire. Another such group were the Canaanite kings and Abram's relative Lot, whom the Judaeans/Jews could regard as the forefathers of neighbouring ethnic groups.

The call for contributions to this special issue of Religions, focussing on constructions of Persian identity and cultural imagination, asked, among other things, how oneself and others are construed in terms of ethnic identity markers and how the imperial setting impacts identity constructions. In response to this, the present article has attempted to analyse the narrative in Genesis $14^{*}$ about Abram's war with the alliance headed by King Chedorlaomer of Elam in Genesis $14^{*}$. In the end, the narrative treats King Chedorlaomer of Elam, the other kings in his alliance, and the other minor players in the narrative (Lot and the Canaanite kings) as pawns. Their role is to represent "the Others" and make Abram shine in the narrative that this article explores to read as a Judaean/Jewish constitutive myth from the Persian or Hellenistic period.

Funding: This research received no external funding.

Conflicts of Interest: The author declares no conflict of interest.

\section{Notes}

Scholars debate what designation one should use for the people associated with the province Judah and the deity Yahweh in antiquity. The terms Judaean and Yehudite are derivations of the place names Judah (Hebrew), Yehud (Aramaic), and Judaea (Latin). In modern usage, the term Jewish probably has a slightly more religious meaning, disconnected from the place name. For the sake of simplicity, this article mostly uses the double designation Judaean/Jewish. 
2 In Gen 17: 5, Yahweh changes the patriarch's name from Abram to Abraham. This article will use the version of the name that is apt in the narrative context in question.

3 In this article, the asterisk in Gen $14^{*}$ signifies chapter 14 without the Melchizedek episode in verses 18-20. The article argues that the Melchizedek episode was secondary in the narrative framework.

4 Gen 14: 17 reports that the king of Sodom went out to meet Abram at the Valley of Shaveh. Suddenly, in vv. 18-20 a new figure appears who has not been introduced earlier in the narrative: King Melchizedek of Salem. After bringing out bread and wine and blessing Abram and El Elyon, Melchizedek disappears as suddenly as he first appeared. Then, in Gen 14: 21 the king of Sodom again speaks to Abram, apparently unaffected by the Melchizedek intermezzo. Neither here nor later in Genesis 14 are there any references to Melchizedek.

$5 \quad$ NRSV $=$ National Council of the Churches of Christ (1989). New Revised Standard Version of the Bible. New York City: National Council of the Churches of Christ.

6 Christoph Berner undertakes a redaction critical analysis of the chapter. He argues that the chapter results from an underlying source (Gen 14:[1*], 2, $8^{*}, 10 \mathrm{a}, 11^{*}$ ). It describes the defeat of the kings of Sodom and Gomorrah. Besides, there are five editorial layers. All of the five layers are so-called post-Priestly, meaning that they stem from layers later than the Priestly Source (the latest primary source of the Pentateuch, according to the dominating theory of the origin of the Pentateuch). The post-Priestly editorial layers "reflect a successive differentiation of the narrative plot with regard to the military protagonists, their alliances and the distribution of the plunder", and "priestly issues" (Berner 2015a, p. 34).

7 The intertextual connection between Gen 15: 1 (Yahweh's oracle to Abram) and Gen 14: 20 (Melchizedek's doxology of El Elyon) represents a potential exception. Both verses use the Hebrew word root $m g n$, albeit with entirely different meanings. In Gen 14: 20, the meaning is "[El Elyon] has delivered your enemies" into Abram's hands. In Gen 15: 1, Yahweh says to Abram: "I am your shield". The Melchizedek episode in Gen 14: 18-20 is a later insertion into Gen $14^{*}$. This explains the intertextual connection between Gen 14: 18-20 and Gen 15: 1.

8 The German term Leerstelle is borrowed from aesthetics of reception theory and translates approximately as "literary gap".

9 It has been suggested that Ezra 4: 6-16 relates to Judaean participation in Egypt's rebellion against Xerxes I (486-465 BCE), which the latter quenched in 483 BCE. Regardless if this is correct or not, the Ezra text is an "indication that loyalty to the Great King was not always a constant feature of Jewish life in the empire", (Perdue et al. 2015, p. 122).

10 The background of the term "slave(s)" in Neh 9: 36 may be the Persian concept of bandaka, which is an obedient servant who acts in favour of Persian power (Becking 2020, p. 114).

$11 \quad$ Media $\approx$ Persia: Jer 51: 11; Esth 1: 3, 18-19; 10: 2; Dan 6: 1; 11: 1; 8: 20, cf. Dan 5: 28; 6: 9.13. See also how Jer 32: 11 LXX reads “all the kings of the Persians" where the parallel Hebrew text in MT Jer 25: 25 instead reads "all the kings of Media". However, 2 Macc 1: 19 lets Persia stand for Babylonia.

12 Thanks to Gian Pietro Basello ("L'Orientale" University of Naples, Italy) for discussing this with me (in a personal communication).

13 The author of the present article disagrees with Peter Dubovskýs suggestion (2018, p. 36) that the translators saw the fall of Elam as an indirect prophecy of the Persian Empire's fall and the rise of the Parthian kingdom. Instead, it is more likely that they identified Elam in Jer 24: 14-26: 1 LXX with Persia and its successor, Parthia.

14 In 2 Sam 8: 12-13, the Masoretic text reads "Aram". However, this reading is odd because of the list of other places that David conquered and in light of the following verse, 2 Sam 8: 14. Therefore, the Septuagint's reading "the Idumaeans" in verses 12-13 probably reflects an older text than the Masoretic text. In Hebrew, the similarity between the letters dalet and resh may have caused a copyist to falsely read the original 'dwm or ' $d m$ ("Edom") as ' $r m$ ("Aram").

\section{References}

Aharoni, Yohanan, and Anson F. Rainey. 1979. The Land of the Bible: A Historical Geography. Philadelphia: Westminster.

Alexander, Philip S. 1992. Geography and the Bible: Early Jewish Geography. In The Anchor Bible Dictionary. D-G. Edited by David

Noel Freedman, Gary A. Herion, David F. Graf, John David Pleins and Astrid B. Beck. New York: Doubleday, vol. 2, pp. 977-88. Allen, Lindsay. 2005. The Persian Empire: A History. London: British Museum Press.

Astour, Michael C. 1966. Political and Cosmic Symbolism in Genesis 14 and in Its Babylonian Sources. In Biblical Motifs: Origins and Transformations. Edited by Alexander Altmann. Cambridge: Harvard University Press, pp. 65-112.

Bartlett, John R. 1982. Edom and the Fall of Jerusalem, 587 B.C. Palestine Exploration Quarterly 114: 13-24. [CrossRef]

Bartlett, John R. 1989. Edom and the Edomites. Sheffield: JSOT Press.

Beattie, Derek R. G., and Philip R. Davies. 2011. What Does Hebrew Mean? Journal of Semitic Studies 56: 71-83. [CrossRef] Becking, Bob. 2020. Identity in Persian Egypt: The Fate of the Yehudite Community of Elephantine. Eisenbrauns: University Park.

Berner, Christoph. 2015a. Abraham amidst Kings, Coalitions and Military Campaigns: Reflections on the Redaction History of Gen 14 and its Early Rewritings. In The Reception of Biblical War Legislation in Narrative Contexts: Proceedings of the EABS Research Group "Law and Narrative". Edited by Harald Samuel and Christoph Berner. Berlin: De Gruyter, pp. 23-60. 
Berner, Christoph. 2015b. Hebrew, Hebrews. In Encyclopedia of the Bible and Its Reception. Halah-Hizquni. Edited by Dale C. Allison, Christine Helmer, Volker Leppin, Choon-Leong Seow, Hermann Spieckermann, Barry Dov Walfish and Eric J. Ziolkowski. Berlin: De Gruyter, vol. 11, pp. 675-80.

Bhabha, Homi K. 2004. The Location of Culture. London: Routledge.

Blenkinsopp, Joseph. 1992. The Pentateuch: An Introduction to the First Five Books of the Bible. New York: Doubleday.

Briant, Pierre. 2002. From Cyrus to Alexander: A History of the Persian Empire. Winona Lake: Eisenbrauns.

Cornell, Collin. 2020. The Costobar Affair: Comparing Idumaism and Early Judaism. Journal of the Jesus Movement in Its Jewish Setting 7: 93-115.

Crowell, Bradley L. 2007. Nabonidus, as-Sila, and the Beginning of the End of Edom. Bulletin of the American Schools of Oriental Research 348: 75-88. [CrossRef]

Dearman, Andrew J. 1995. Edomite Religion. A Survey and an Examination of Some Recent Contributions. In You Shall Not Abhor an Edomite For He Is Your Brother: Edom and Seir in History and Tradition. Edited by Diana Vikander Edelman. Atlanta: Scholars Press, pp. 119-36.

Dicou, Bert. 1994. Edom, Israel's Brother and Antagonist: The Role of Edom in Biblical Prophecy and Story. Sheffield: JSOT Press.

Dozeman, Thomas B. 2009. Commentary on Exodus. Edited by David Noel Freedman and Astrid B. Beck. Grand Rapids: Eerdmans.

Driver, Samuel Rolles. 1905. The Book of Genesis, 4th ed. London: Methuen.

Dubovský, Peter. 2018. Elam and the Bible. In The Elamite World. Edited by Javier Álvarez-Mon, Gian Pietro Basello and Yasmina Wicks. New York: Routledge, pp. 27-40.

Edelman, Diana Vikander. 1995. Edom: A Historical Geography. In You Shall Not Abhor an Edomite For He Is Your Brother: Edom and Seir in History and Tradition. Edited by Diana Vikander Edelman. Atlanta: Scholars Press, pp. 1-12.

Emerton, John Adney. 1971. Some False Clues in the Study of Genesis XIV. Vetus Testamentum 21: 24-47. [CrossRef]

Emerton, John Adney. 1990. Some Problems in Genesis XIV. In Studies in the Pentateuch. Edited by John Adney Emerton. Leiden: Brill, pp. 73-102.

Foster, Benjamin R. 2005. Before the Muses: An Anthology of Akkadian Literature, 3rd ed. Bethesda: CDL Press.

Fritz, Volkmar. 2000. Die Grenzen des Landes Israel. In Studies in Historical Geography and Biblical Historiography: Presented to Zecharia Kallai. Edited by Galil Gerson and Moshe Weinfeld. Leiden: Brill, pp. 14-34.

Germany, Stephen. 2020. Melchizedek. I. Hebrew Bible/Old Testament. In Encyclopedia of the Bible and Its Reception. Mass-Midnight. Edited by Constance M. Furey, Brian Matz, Steven L. McKenzie, Thomas Römer, Jens Schröter, Barry Dov Walfish and Eric J. Ziolkowski. Berlin: De Gruyter, vol. 18, pp. 524-26.

Grabbe, Lester L. 1992. Judaism from Cyrus to Hadrian. Minneapolis: Fortress Press.

Granerød, Gard. 2010. Abraham and Melchizedek: Scribal Activity of Second Temple Times in Genesis 14 and Psalm 110. Berlin: De Gruyter.

Granerød, Gard. 2013. "By the Favour of Ahuramazda I Am King": On the Promulgation of a Persian Propaganda Text among Babylonians and Judaeans. Journal for the Study of Judaism 44: 455-80. [CrossRef]

Granerød, Gard. 2016. Dimensions of Yahwism in the Persian Period: Studies in the Religion and Society of the Judaean Community at Elephantine. Berlin: De Gruyter.

Granerød, Gard. 2019. Canon and Archive: Yahwism in Elephantine and hūdu as a Challenge to the Canonical History of Judean Religion in the Persian Period. Journal of Biblical Literature 138: 345-64. [CrossRef]

Hutchinson, John, and Anthony D. Smith. 1996. Introduction. In Ethnicity. Edited by John Hutchinson and Anthony D. Smith. Oxford: Oxford University Press, pp. 3-16.

Kallai, Zecharia. 1998. The Campaign of Chedorlaomer and Biblical Historiography. In Biblical Historiography and Historical Geography: Collection of Studies. Edited by Zecharia Kallai. Frankfurt am Main: Peter Lang, pp. 218-42.

Kelley, Justin. 2009. Toward a New Synthesis of The God of Edom and Yahweh. Antiguo Oriente 7: 255-80.

Knauf, Ernst Axel. 1984. Qaus. Ugarit-Forschungen 16: 93-95.

Knauf, Ernst Axel. 1999. Qôs. In Dictionary of Deities and Demons in the Bible (DDD). Edited by Karel van der Toorn, Bob Becking and Pieter Willem van der Horst. Leiden: Brill, pp. 674-77.

Knauf-Belleri, Ernst Axel. 1995. Edom: The Social and Economic History. In You Shall Not Abhor an Edomite For He Is Your Brother: Edom and Seir in History and Tradition. Edited by Diana Vikander Edelman. Atlanta: Scholars Press, pp. 93-118.

Köckert, Matthias. 1988. Vätergott und Väterverheißungen: Eine Auseinandersetzung mit Albrecht Alt und seinen Erben. Göttingen: Vandenhoeck \& Ruprecht.

Köckert, Matthias. 2017. Abraham: Ahnvater_Vorbild-Kultstifter. Leipzig: Evangelische Verlagsanstalt.

Köhler, Ludwig, Walter Baumgartner, Johann Jakob Stamm, Benedikt Hartmann, and Mervyn E. J. Richardson. 2000. The Hebrew and Aramaic Lexicon of the Old Testament. Leiden: Brill.

Kratz, Reinhard Gregor. 2005. The Composition of the Narrative Books of the Old Testament. London: T\&T Clark.

Kuhrt, Amélie. 2007. The Persian Empire: A Corpus of Sources from the Achaemenid Period. London: Routledge.

Kuhrt, Amélie. 2020. The Persian Empire. In Aršāma and Egypt: The Bodleian Letters in Context. Aršāma's World. Edited by Christopher Tuplin and John Ma. Oxford: Oxford University Press, vol. 3, pp. 123-35.

Lemche, Niels Peter. 1992a. Habiru, Hapiru. In The Anchor Bible Dictionary. H-J. Edited by David Noel Freedman, Gary A. Herion, David F. Graf, John David Pleins and Astrid B. Beck. New York: Doubleday, vol. 3, pp. 6-10. 
Lemche, Niels Peter. 1992b. Hebrew. In The Anchor Bible Dictionary. H-J. Edited by David Noel Freedman, Gary A. Herion, David F. Graf, John David Pleins and Astrid B. Beck. New York: Doubleday, vol. 3, p. 95.

Levin, Yigal. 2020. The Religion of Idumea and Its Relationship to Early Judaism. Religions 11: 487. [CrossRef]

Lindenberger, James M. 2003. Ancient Aramaic and Hebrew Letters, 2nd ed. Atlanta: Society of Biblical Literature.

Lindsay, John. 1976. The Babylonian Kings and Edom, 605-550 B.C. Palestine Exploration Quarterly 108: 23-39. [CrossRef]

Lipschits, Oded. 2018. Abraham zwischen Mamre und Jerusalem. In The Politics of the Ancestors: Exegetical and Historical Perspectives on Genesis 12-36. Edited by Mark G. Brett, Jakob Wöhrle and Friederike Neumann. Tübingen: Mohr Siebeck, pp. 187-209.

Lipschits, Oded, Thomas Römer, and Hervé Gonzales. 2017. The Pre-Priestly Abraham Narratives from Monarchic to Persian Times. Semitica 59: 261-96. [CrossRef]

Lundbom, Jack R. 2013. Deuteronomy: A Commentary. Grand Rapids: Eerdmans.

Machiela, Daniel A. 2009. The Dead Sea Genesis Apocryphon: A New Text and Translation with Introduction and Special Treatment of Columns 13-17. Leiden: Brill.

McKane, William. 1996. Jeremiah. Jeremiah 26-52. Edinburgh: T\&T Clark, vol. 2.

Meyers, Carol L. 2005. Exodus. Cambridge: Cambridge University Press.

Na'aman, Nadav. 2015. Abraham's Victory over the Kings of the Four Quadrants in Light of Darius I's Bisitun Inscription. Tel Aviv 42: 72-88. [CrossRef]

Na'aman, Nadav. 2016. The Boundaries of the Promised Land in the Patriarchal Narratives. Biblische Notizen. Neue Folge $170:$ 3-12.

National Council of the Churches of Christ. 1989. New Revised Standard Version of the Bible. New York: National Council of the Churches of Christ.

Nelson, Richard D. 2002. Deuteronomy: A Commentary. Louisville: Westminster John Knox Press.

Noort, Edward. 1998. Das Buch Joshua: Forschungsgeschichte und Problemfelder. Darmstadt: Wissenschaftliche Buchgesellschaft.

Noth, Martin. 1968. Numbers: A Commentary. London: SCM Press.

Ottosson, Magnus. 1991. Josuaboken: En Programskrift för Davidisk Resturation. Uppsala: Almqvist \& Wiksell International.

Perdue, Leo G., Warren Carter, and Coleman A. Baker. 2015. Israel and Empire: A Postcolonial History of Israel and Early Judaism. London: Bloomsbury T\&T Clark.

Person, Raymond F. 2010. The Deuteronomic History and the Book of Chronicles: Scribal Works in an Oral World. Atlanta: Society of Biblical Literature.

Pitard, Wayne T. 1992. Damascus (Place). Pre-Hellenistic History. In The Anchor Bible Dictionary. D-G. Edited by David Noel Freedman, Gary A. Herion, David F. Graf, John David Pleins and Astrid B. Beck. New York: Doubleday, vol. 2, pp. 5-7.

Porten, Bezalel, and Ada Yardeni. 2014-2020. Textbook of Aramaic Ostraca from Idumea. Winona Lake: Eisenbrauns.

Rendtorff, Rolf. 1985. The Old Testament: An Introduction. London: SCM Press.

Rofé, Alexander. 1999. Introduction to the Composition of the Pentateuch. Sheffield: Sheffield Academic Press.

Römer, Thomas. 2007. The So-Called Deuteronomistic History: A Sociological, Historical and Literary Introduction. London: T\&T Clark.

Römer, Thomas. 2018. Die politische Funktion der vorpriesterlichen Abrahamtexte. In The Politics of the Ancestors: Exegetical and Historical Perspectives on Genesis 12-36. Edited by Mark G. Brett and Jakob Wöhrle. Tübingen: Mohr Siebeck, pp. $211-32$.

Sæbø, Magne. 1974. Grenzbeschreibung und Landideal im Alten Testament: Mit besonderer Berücksichtigung der min- $a d-F o r m e l$. Zeitschrift des Deutschen Palästina-Vereins 90: 14-37.

Salaris, Davide. 2019. First Elymaic Attestation of Elymais. Nouvelles Assyriologiques Brèves et Utilitaires 3: 147-49.

Schatz, Werner. 1972. Genesis 14: Eine Untersuchung. Bern: Herbert Lang Bern/Frankfurt am Main Peter Lang.

Smith, Anthony D. 1986. The Ethnic Origins of Nations. Malden: Blackwell.

Stolper, Matthew W. 1989. The Governor of Babylon and Across-the-River in 486 B.C. Journal of Near Eastern Studies 48: $283-305$. [CrossRef]

Stoltz, Gerhard P. J., and Andries P. B. Breytenbach. 2001. Genesis 14-'n redaksie-kritiese ondersoek. Hervormde Teologiese Studies 57: 1312-43. [CrossRef]

Thompson, Henry O. 1992. Hobah (Place). In The Anchor Bible Dictionary. H-J. Edited by David Noel Freedman, Gary A. Herion, David F. Graf, John David Pleins and Astrid B. Beck. New York: Doubleday, vol. 3, p. 235.

Tuplin, Christopher. 2020. Aršāma: Prince and Satrap. In Aršāma and Egypt: The Bodleian Letters in Context. Aršāma's World. Edited by Christopher Tuplin and John Ma. Oxford: Oxford University Press, vol. 3, pp. 3-72.

Vriezen, Theodorus C. 1965. The Edomite Deity Qaus. Oudtestamentische Studiën 14: 330-53.

Westermann, Claus. 1985. Genesis 12-36: A Commentary. Minneapolis: Augsburg.

Wiesehöfer, Josef. 2001. Ancient Persia: From 550 BC to 650 AD. London: I.B. Tauris.

Yee, Gale A. 2010. Postcolonial Biblical Criticism. In Methods for Exodus. Edited by Thomas B. Dozeman. Cambridge: Cambridge University Press, pp. 193-233.

Zimmerli, Walther. 1969. Ezechiel. Neukirchen-Vluyn: Neukirchener Verlag. 